\title{
The Organizational Gift and Sociological Approaches to Exchange
}

\author{
Philippe Steiner
}

N63 | february 2014

\begin{abstract}
This paper studies the specific form of gift-giving behavior in which an organization, or a set of organizations, intervenes between the donor and the donee. It is suggested that this should be called an organizational gift, or "organic gift". Following Richard Titmuss' insights, the first part considers what happens in the domain of biomedicine, examining here what is meant by a "gift" in the case of organ transplantation, in contrast to the Maussian conceptualization of gift-giving behavior. The second part elaborates this finding, and delineates the main characteristics of this modern form of gift, entailing the presence of organizations in the absence of which the donor and the donee could neither give nor receive. The final part broaden the perspective, including a review of Karl Polanyi's conception of reciprocity as an integrative form of economic activity, providing a new way of mapping the forms of exchange which present themselves as alternatives to market exchange in our current market societies.
\end{abstract}




\title{
The Organizational Gift and Sociological Approaches to Exchange
}

\author{
Philippe Steiner
}

February 2014

\section{L'auteur}

Philippe Steiner est professeur de sociologie à l'université Paris-Sorbonne et membre de l'Institut universitaire de France. Chercheur au GEMASS, il conduit ses recherches sur la sociologie économique et l'histoire des sciences sociales. Il a récemment publié La transplantation d'organes : un commerce nouveau entre les êtres humains (Gallimard, 2010) et Durkheim and the Birth of Economic Sociology (Princeton university press, 2011).

\section{Le texte}

Une première version de ce texte a été présentée lors de la conférence « New Developments in Economic Sociology ", organisée par l'université d'Uppsalla, en septembre 2013.

Ce papier est publié par le Groupe d'étude des méthodes de l'Analyse sociologique de la Sorbonne (GEMASS - CNRS, Paris Sorbonne, FMSH) à Paris, dans la collection de working papers de la Fondation Maison des sciences de l'homme.

Site Internet du GEMASS : http://gemass.fr/

\section{Citer ce document}

Philippe Steiner, The Organizational Gift and Sociological Approaches to Exchange, FMSH-WP-2014-63, GeWoP-6, february 2014.

C) Fondation Maison des sciences de l'homme - 2013

Informations et soumission des textes :

wpfmsh@msh-paris.fr

Fondation Maison des sciences de l'homme 190-196 avenue de France 75013 Paris - France

http://www.msh-paris.fr http://halshs.archives-ouvertes.fr/FMSH-WP http://wpfmsh.hypotheses.org
Les Working Papers et les Position Papers de la Fondation Maison des sciences de l'homme ont pour objectif la diffusion ouverte des travaux en train de se faire dans le cadre des diverses activités scientifiques de la Fondation : Le Collège d'études mondiales, Bourses Fernand Braudel-IFER, Programmes scientifiques, hébergement à la Maison Suger, Séminaires et Centres associés, Directeurs d'études associés...

Les opinions exprimées dans cet article n'engagent que leur auteur et ne reflètent pas nécessairement les positions institutionnelles de la Fondation MSH.
The Working Papers and Position Papers of the FMSH are produced in the course of the scientific activities of the FMSH: the chairs of the Institute for Global Studies, Fernand Braudel-IFER grants, the Foundation's scientific programmes, or the scholars hosted at the Maison Suger or as associate research directors. Working Papers may also be produced in partnership with affiliated institutions.

The views expressed in this paper are the author's own and do not necessarily reflect institutional positions from the Foundation $\mathrm{MSH}$. 


\section{Abstract}

This paper studies the specific form of gift-giving behavior in which an organization, or a set of organizations, intervenes between the donor and the donee. It is suggested that this should be called an organizational gift, or "organic gift". Following Richard Titmuss' insights, the first part considers what happens in the domain of biomedicine, examining here what is meant by a "gift" in the case of organ transplantation, in contrast to the Maussian conceptualization of gift-giving behavior. The second part elaborates this finding, and delineates the main characteristics of this modern form of gift, entailing the presence of organizations in the absence of which the donor and the donee could neither give nor receive. The final part broaden the perspective, including a review of Karl Polanyi's conception of reciprocity as an integrative form of economic activity, providing a new way of mapping the forms of exchange which present themselves as alternatives to market exchange in our current market societies.

\section{Keywords}

gift, Mauss, organisation, Polanyi, transplantation

\section{Les dons organisationnels et I'approche sociologique des échanges}

\section{Résumé}

Cet article étudie la forme particulière de don qui est à l'ouvre lorsqu'une organisation, ou un ensemble d'organisations, prend place entre le donateur et le donataire. Ce que l'on peut appeler don organisationnel ou don organique. A la suite des réflexions de Richard Titmuss, la première partie de l'article étudie le déroulement du don dans la transplantation d'organes. La seconde partie caractérise cette nouvelle forme de don dans laquelle en l'absence des organisations le donateur et le donataire ne pourraient se rencontrer. La dernière partie de l'article montre comment le don organisationnel prend place dans une version renouvelée de la cartographie polanyienne des échanges.

\section{Mots-clefs}

don, Mauss, organisation, Polanyi, transplantation 


\section{Sommaire}

Transplant surgery and the organizational gift 5

Organizational gift, gift and market exchange 8

Reciprocity and alternatives forms

of exchange in modern economies

$\begin{array}{ll}\text { Polanyi's four types of economic integration } & 13\end{array}$

What "reciprocity" means in a market-system society 14

Forms of integration and the relational dimensions of economic integration

Conclusion

References 
S ince the middle of the 19th Century sociologists have known that, beyond market exchanges, there exists in any given society a plurality of modes of transferring goods. Accordingly, they have devoted an important part of their inquiries to explaining the functioning of these alternatives to market exchanges: inheritance and gift in Auguste Comte's Système de politique positive; gift in Marcel Mauss' Essai sur le don; and symbolic exchange in a series of papers written by Pierre Bourdieu in the 1970s. I cannot here deal with the whole set of these modes of exchange, so I will focus on what happens in the domain of biomedicine, particularly in organ transplantation. The main finding is that there exists a specific form of gift-giving behavior in which an organization, or a set of organizations, intervenes between the donor and the donee. I suggest that this should be called an organizational gift. Some of its characteristics were explained in Richard Titmuss' study, when he emphasized how the gift of blood differed from the gift considered by anthropologists; notably because there is no longer a direct connection between donor and recipient. In the organizational gift there is no similarity between both individuals, connected only by the willingness of one of them to help a suffering "stranger".

Following Richard Titmuss' insights, the first part of the paper will consider what happens in the domain of biomedicine, examining here what is meant by a "gift" in the case of organ transplantation, in contrast to the Maussian conceptualization of gift-giving behavior. The second part of the paper will elaborate this finding, and delineate the main characteristics of this modern form of gift, entailing the presence of organizations in the absence of which the donor and the donee could neither give nor receive. In the final part I will broaden my perspective, including a review of Karl Polanyi's conception of reciprocity as an integrative form of economic activity, providing a new way of mapping the forms of exchange which present themselves as alternatives to market exchange in current market societies.

\section{Transplant surgery and the organizational gift}

There is almost universal agreement that the surgical practice of transplantation is founded upon gift-giving behaviors; from the 1950s to the present, both medical and political worlds have relentlessly opposed the commodification of human body parts - the only exception is in Iran, where a biomarket for kidneys was made legal in 1987. In parallel to the case of blood that was central to Titmuss's approach, organ transplantation surgery has introduced a new and unusual form of gift. However, the issue of what is actually given, and to whom, remains complex. French legislation from the 1970s up to the present-day is a case in point.

According to this legislation, organ gift-giving means essentially that the person whose organs are removed, whether dead or alive, receives nothing, whether cash or any other material advantage, as a counterpart for that person's gift. Furthermore, the French legislature decreed in 1978 that all French citizens were deemed to have given their consent to post-mortem donation. Following a lengthy debate, revision in 2011 of the bioethical law (Loi de bioéthique) made it possible, in the case of living donation, that the living donor receive some payment to cover the costs incurred in making this altruistic gift. But this payment should never be confused with any direct or indirect payment for the organ itself. Hence from the legal point of view a gift is made according to article 894 of the French Civil Code, which runs as follows: "Inter vivos donation is an act through which the donor makes an actual and irrevocable transfer to the benefit of the donee who accepts it". This form of resource transfer is clearly quite unlike the selling of a good, which is "a convention by which one party undertakes to deliver something and his counterpart undertakes to pay for it" (art. 1582); it is also unlike exchange behavior, which is defined as "a contract by which those involved give one thing in exchange for another" (art. 1702). Gift-giving behavior precludes the existence of the counterpart that is central to the definition of both selling and exchanging.

This legal definition does not fit the sociological approach of gift-giving behaviors, notably that which Mauss proposed in his famous study published in L'Année sociologique (Mauss 1925) including the three obligations: to give, to receive and to give back. There is thus a sharp contrast between the sociological and the legal approach. From the legal point of view, a gift entails free will since the idea of an obligation to part with something would be meaningless - the mingling of freedom and obligation so often mentioned in Mauss's writings is likewise ruled out. 
Furthermore, the idea of an obligation to receive is also absent from the legal point of view, since one article of the French Civil Code states that a donation is effective only when the donee has explicitly accepted the gift. Finally, any obligation to give back is explicitly ruled out by the definition provided in article 894. Given such discrepancy between legal and social approaches, it is necessary to consider carefully in what sense organ donation can be considered sociologically as a gift.

In order to get a clear picture of what is meant by organ donation, I suggest that the materiality of gift-giving behavior be considered with respect to transplant surgery.

In the case of post mortem procurement, donation occurs within the medical organization. Death, and more precisely brain death, requires the intervention of several specialists able to read data provided by (usually) two successive encephalograms; if the person assigned to an intensive care unit is declared dead while her heart is still beating and her lungs inhaling oxygen and expelling carbonic gas, then the process of donation can begin. Since the dead person has rarely spelled out what should be done with her organs in such a situation, transplant teams have to meet the family or the relatives in order to get their consent to perform the surgery necessary to extract living organs from the dead body. This is compulsory when the legislation requires an explicit consent, but this is also practically what happens when presumed consent applies because surgeons are very anxious about possible negative reactions from grieving families, as well as public opinion concerning what might appear to be the unethical harvesting of organs. Is this a gift? The donor does not actually give her organs, since she is dead. If there is a gift, it comes from family members or relatives who give their consent to the surgery necessary to open the body and extract organs. What about inter vivos gift-giving? In that case, the person actually decides by herself to give or not to give this right to extract a kidney, a lobe of her liver or, more rarely, a part of one of her lungs. Furthermore, in most cases, longstanding affective relations between the donor and the recipients are the basis of the donation. We may thus consider that, in this specific case, Maussian obligations are at work: a moral obligation to give to a relative facing bad health or, worse, facing death; an obligation to receive in order to escape painful, time-consuming and costly dialysis; a moral obligation to give back to the one who chose to help you when you were in a medical distress. However, even in that case, the medical organization remains central: it is the medical staff who decides if a relative may or may not give, according to medical and psycho-sociological standards and guidelines. The medical organization remains central because the medical staff performs the surgery, and also because of the complex follow-up for both donor and recipient.

The technical dimension managed and performed by the organization is thus central in both forms of donation. There is a quantitative proof of that centrality: annual reports of the French organization in charge of the coordination of all transplant activity in the country provides information about the rejection of organs given by the relatives of brain-dead patients. These reports make clear that, contrary to what is commonly thought when a gift is under consideration, biomedical gifts are commonly discarded by the organization. In 2006 the report regretted that $31 \%$ of the families approached for a gift turned down the offer, but it also mentioned that $18 \%$ of potential donors did not become actual donors because of medical obstacles, or because of antecedent conditions in the donors. In 2011 these figures were unchanged. Similarly, people willing to give a kidney to a relative or a spouse may be prevented from doing so if their medical status and/or socio-psychological profile do not meet the legal and medical requirements for a nephrectomy to be performed. In France, as in most countries, living donation entails both technical and relational dimensions or, to put it in other words, legal-medical obligations and moral ones; it is thus impossible to consider only the relational and moral dimension, as a Maussian approach would suggest.

This does not just amount to saying that biomedical gifts are "a bit more complex" than usual gifts, those that one may perform in the course of daily activity. From a sociological point of view, a biomedical gift has a greater resemblance to a sacrifice - a social configuration close to a gift - than to a Maussian gift. What is the difference between a sacrifice and a gift? According to the work of Mauss and his friend and colleague Henri Hubert (1898), the difference comes from the presence of a third party in the configuration. While the gift is a performance in which the donor and the donee meet and proceed to the actualization of the first two obligations (to give 
and to receive) before they meet in the future to reverse their position (the third obligation turns the donee into a donor and vice-versa), this is not the case with sacrifice, because between those who expect something from it and the person or the thing sacrificed there is a third party, the sacrificer, whose technique is necessary to the efficient performance of the ritual - a very "technical" ritual in the case of organ transplantation. In the post mortem production of the organ (the "scarce resource" of this commerce) the dead person is the one to be sacrificed. Qualified members of the medical organization are the professionals whose command over the medical technique ensures that the sacrifice can be performed according to the prescribed ritual (determined in this case by medical efficiency considered as a value). The last party of this configuration is the family, who might expect no more than a moral benefit from the "gift" - namely, the benefit related to helping an unknown human being, thus giving a meaning to the sudden and unexpected death of a relative. Sacrifice represents a useful step so that we might arrive at the idea of the organizational gift.

In order to gain a full picture of the system of social relations that support transplantation as a new form of commerce among human beings a final party to the transaction has to be considered: the donee. Once the organ is produced, the scarce resource moves swiftly from the initial organization to the final one, the operating theatre in which the organ is grafted into the body of the recipient. To this final individual in the transplant relational chain, the organ appears to be a gift since it is received free of charge, in the sense that this individual does not have to meet the (very great) cost of the medical procedure. It is also a gift because the recipient cannot legally oblige anybody to give a kidney; there is no obligation beyond the moral one, even if this moral obligation is itself the result of organizational work. This final step is the reason why the sociological definition of sacrifice is not sufficient to make sense of the whole process, even if it offers the possibility of understanding the role played by professionals, and the organization in which they act.

To conclude this first point, the role and centrality of the medical organization are so prominent that I suggest that this form of transfer of resource be considered as a genuine form of gift, an organizational gift. This is, I suggest, its main sociological characteristic. From a morphological point of view, to use a Durkheimian category, it means (see figure 1) that the production, distribution and use of the scarce resource cannot be achieved without the organizational intervention that occurs between the first individual (the donor) and the final individual (the recipient). When there are a stringent time constraints and a high sensitivity of the public to equity issues, medical organizations are coordinated by a "supervising organization" (UNOS in the United States, Agence de la Biomédecine in France) that may have some legal power over lower level organizations. As a consequence, the organizational gift is an "armslength gift", or a "gift at distance", compared to the direct gift theorized by Mauss. Most generally, this means that both individuals are not in direct contact, they remain "strangers" to each other.

It is worth stressing the fact that such situations are not limited to organ transplantation, and not limited to the domain of biomedicine (see, for example, Barman 2007). Basically, the organizational gift was already central in blood transfusion, from the interwar period up to the present. Some of its characteristics were explained in Titmuss' study, when he emphasized how the gift of blood differed from the gift considered by anthropologists such as Mauss and Claude Levi-Strauss (Titmuss 1970, p. 276-279); notably because, with organizations intervening, there is no longer a direct connection between donor and recipient. In that sense, following Emile Durkheim's famous distinction, the organizational gift can

Figure 1 : Organizational gift

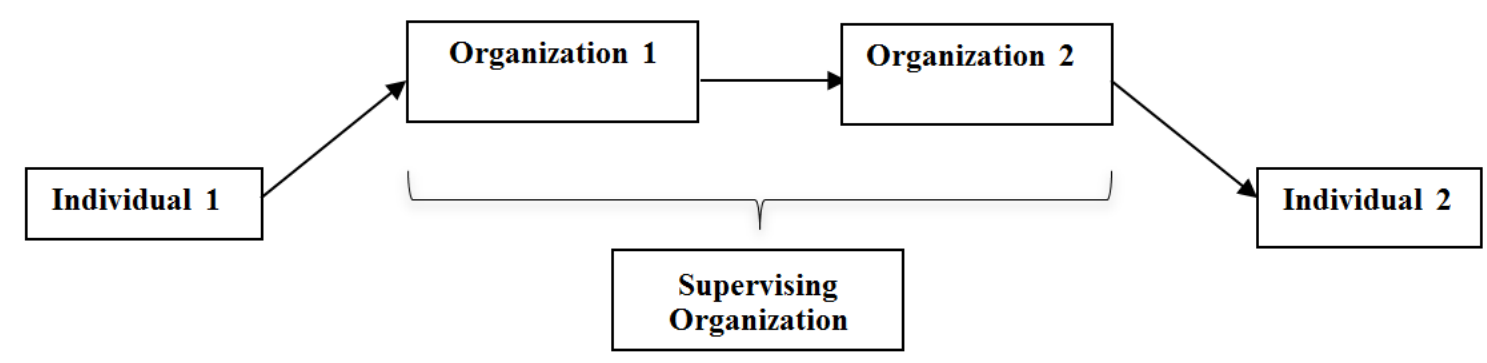


be labeled an "organic gift": beyond the fact that they are both human beings, there is no similarity between both individuals, they can belong to highly differentiated social groups, and be connected only by the willingness of one of them to help a suffering "stranger", far removed from them. The division of labor in society applies equally to market exchange and to gift-giving behavior. However, beyond blood and organs, there are other situations in which organizations are central to the modern gift. This is the case with sex cells, a most interesting case because of the wide set of solutions - from commodification to various forms of gift (with or without anonymity, direct or indirect gift, required counter-gift, etc.) - that result from different national regulations, or lack of regulation (Melh 2008, Théry 2010, Almeling 2011).

One important point that medically-assisted procreation brings to the fore is the relational dimension of organizational gift. For several decades the anonymity of the gift was taken for granted since it was in the domain of organ transplantation: anonymity permitted the couple not to tell member of their inner circle how the children were conceived. It was even possible not to say anything to the children themselves. The situation changed dramatically when same sex couples stepped in since, in that case, anonymity was meaningless on the one hand and, on the other, these couples were eager to get more information from the potential donors and more opportunity to choose the donor fitted to their wish than other couples could (Almeling 2011, p. 34-5; Thery 2010, p. 43-4). Last but not least, some decades after the success of medicallyassisted procreation, some of the children who had become aware of how they were conceived wished to be given information about one of their biological parents in order to fill a gap in their personal identity. This has major consequences for the organization of the donation, whether framed in terms of labor for the men selling sperm, or in terms of altruism for the women selling eggs (Almeling 2011), since this means that one of the central element put forward in Titmuss' analysis does not hold: the organizational gift may require that "two steps strangers" meet. In such a situation the organizational gift forbids the usual "give and forget" solution, and induces potential relations at a remote stage. This is of consequence for all the parties and for the sociological understanding of this form of organizational gift.

\section{Organizational gift, gift and market exchange}

A gift is usually associated with reciprocity. Where does the organizational gift stand? The notion of the organizational gift is missing from the sociological approach to the gift, as represented by Philippe Chanial's otherwise comprehensive collection of surveys of gift-giving practices (Chanial 2009). It is the same with the classic book written by Jacques Godbout and Alain Caillé (1992). To see how the organizational gift belongs to the wide domain of reciprocity it is necessary to consider how the presence of organizations modifies the situation.

The organizational gift involves two consequences:

- Two types of actor take part in an organizational gift: individual persons, and moral persons (or organizations).

- Relations exist between organizations themselves, relations that have no reason to belong to the category of gift, irrespective of the nature of the relationship between the individuals at each end of the circuit of commerce.

Modern societies are not solely constituted of persons in the sense of physical individuals, as it is the case with traditional view of the giftgiving practices occurring in archaic societies. According to James Coleman (1982), in modern society there are two types of actor capable of intervening in the transfer of resources: physical persons on the one hand; and on the other organizations, which are moral persons. The resources over which each of these persons has control differ, and this difference has an impact upon the relations that can exist between them. Physical persons have no resources other than those that belong to them - fungible property and human capital - plus those held by persons, but which belong to their network of acquaintances formed by their family, religious connections and their social neighborhood - what Coleman called social capital. Moral persons can in general make use of all the resources accumulated in the group created for the purpose of undertaking a given activity. This distinction highlights a major asymmetry between actors, and it becomes necessary to take account of the status of the latter to understand the nature of the social relations that they maintain. 
Figure 2 : Typology of transactions

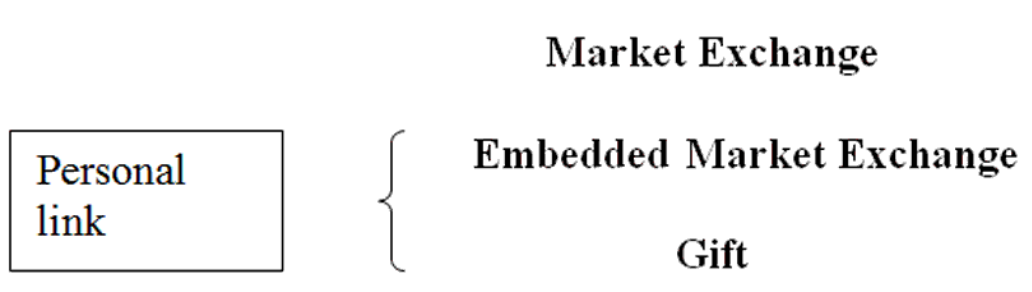

\begin{tabular}{|l|}
\hline $\begin{array}{l}\text { Personal } \\
\text { link }\end{array}$ \\
\hline
\end{tabular}

\author{
Embedded Market Exchange \\ Gift
}

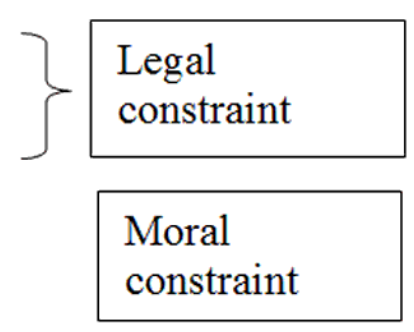

I therefore propose to distinguish personal social relations from functional or impersonal social relations, or alternatively personal friendship and professional friendship. Personal relations and personal friendship arises where actors are physical persons. This does not hold for relations between organizations, or between an organization and a person. In this latter case, while the individual member of the organization is of course a physical person, that person occupies a role that can require detachment and the management of personal feelings (Hochschild 2003). On the one hand this individual is interchangeable with other members of the same organization; and on the other, relating to clients of the organization, this individual has no reason to extend the relation with this client beyond the duration of the transaction, even if this is of long duration. This point also serves as proof of the difference between the two types of relation: if the relation between the individual member of the organization and the person addressed persists even when the first leaves the organization and/or the second ceases to be a client, it is reasonable to think that the relationship has acquired a personal status. The two persons involved now engage according to the formula "because it's me, because it's him" with which Michel de Montaigne characterized his friendship with Etienne de la Boétie. The same sort of thing can be said for relations between two individuals holding posts in organizations, and of their relationships in the framework of market relationships between organizations: two individuals can be in a situation of professional friendship, paying attention and exchanging presents as occupants of positions that place them in a working relationship. Proof of this can be seen when one of them retires, changes employer, or position: will he receive the same attention, the same presents as his predecessor?
With this distinction in mind, it is thus possible to go beyond the typology of transfer of resource (Figure 2) set by contemporary anthropologists (Descola 2005, Testart 2007) for contrasting gift and market relations on the basis of the difference between two forms of constraint (moral and legal) and the absence or existence of personal links between the exchanging parties. The intermediary type appears when the transaction involves personal relations and legal constraints salient in the case when the good is not for sale, but the owner is willing to sell it to one of his friend who wants to buy it. This is what can be considered as an "embedded market transaction".

Adapting the typology to the framework of an “organized" society (Figure 3), I suggest how we might take account of moral persons and the relationships corresponding to them: organizational connections. This typology relates personal connections to relationships between persons; and also impersonal connections to relationships between individual members of organizations or also between the latter and persons who are "clients", understood broadly as persons making use of relationships with organizations to obtain the resources which they need.

Relying on moral constraint, the organizational gift belongs to the domain of reciprocity, like the Maussian gift; however, it differs from the latter by the fact that there is no direct and personal link between the donor and the donee. The importance of organization within this form of solidarity may be emphasized on three grounds: tariffs and cost, power relations, and the length of relational chains.

Firstly, the issue of covering the cost of the organization is of paramount importance in organ transplantation. In the case of organ transplantation, and notably in the case of kidney transplantation, the issue of cost is easily forgotten since it 
Figure 3 : Typology of transactions involving organizations

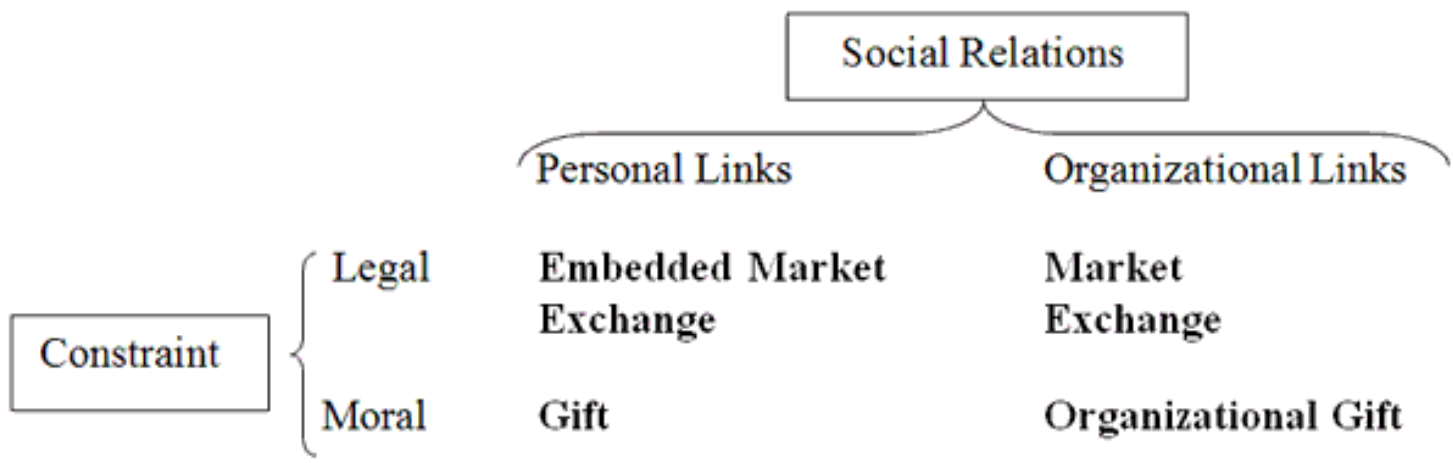

is far below the cost of alternative treatment (dialysis) after the first year - the difference is about 10,000 euros a year in favor of transplantation. In that case, the cost seems to dwindle besides the financial gain accruing to society whenever a kidney is grafted to a patient suffering from endstage kidney failure. Nevertheless, while donation is free, it is also costly - about 7,000 euros in Continental Europe for the procurement of a kidney. The heaviest cost comes from the medical organization itself (surgeons, operating theatres, intensive care units, drugs, follow-up, etc.) which makes transplant surgery the most expensive form of surgery according to the current French tariff, the so-called tarification à l'activité (T2A): from 15,900 euros for a kidney transplant, to 39,000 euros for liver transplant, and up to 63,000 euros for a heart and lung transplant. These tariffs include a standard stay in an intensive care unit; however additional days are common, but costly: from 600 euros a day (heart and lung transplants), to 1,100 euros (lung-heart transplant). It is worth emphasizing that tariffs do take into account the organizational dimension of donation, since hospitals could be funded if their staff assumes co-ordinating the work of various medical organizations in a given area. So in the absence of a biomarket, there is a potential economic sociology of tariffs that can be developed which would uncover how societies deal with costs when there is no market and, consequently, when the price mechanism does not operate.

Broadening the issue of the organizational cost of organizational gifts beyond organ transplantation, one may understand the importance of this point through some data related to a nonprofit association active in the field of medical care. During the years 2004, 2005 and 2006 the association collected respectively 1.8, 1.6 and 1.6 millions euros; and when the cost of fundraising is taken into account, the net amount available is reduced significantly - to $56 \%, 55 \%$ and $47 \%$ of these sums respectively (Avare and Eynaud 2010, p. 163). The organizational cost of raising the organization's resources is only one side of the story. A study conducted for the Fondation de France demonstrates that organizational costs represent a significant burden for the charity sector (Fondation de France, 2008). In 2005, foundations in France spent 339 millions euros: a significant sum indeed, but this is only $9 \%$ of the money they received (about 3.7 billions), since more than $90 \%$ of their funds were used to cover the cost of the organization ${ }^{1}$ and pay the wages of the non-volunteer part of their workforce. Only those organizations linked to public institutions or a private firm did better - they redistributed $89 \%$ of the money they received - because their organizational costs were paid by their host organization.

Secondly, the organizational gift introduces the issue of control and power relations. Usually, power relations are left out the picture of giftgiving behavior largely because, in the case of biological donation, there is no direct connection between the donor and the recipient. However, once the organization is treated as playing a decisive and active part in donation the picture changes, and power relations arise, as Coleman pointed out. The basic idea is simple: when organizations are taken into account, the relational

1. These costs are associated with the origination and diffusion of their programs, program follow-up, expertise, audit, the building of networks, education, conferences and meetings, publications, financial and overhead costs (Fondation de France, 2008, p. 20). 
dimension of donation changes significantly, since the person representing the organization is not there as a mere individual but has to act according to a given script, a given task to be achieved whatever that person's feelings about the matter might be. Further, it may be the case that the organizational script entails the "management of feelings" (Hochschild 2003) as a resource for the task to be performed. Furthermore, organizations have their own specific interests in respect of the control of given resources.

This is particularly true in the case of the bioethical domain. When the first version of the French law on bioethics was debated in Parliament during the years 1992-94, the prime issue was to gain control over surgeons working in hospitals. Some of these surgeons had been involved in irregular allocations of organs that had prevented the collection of the usual number of organs, and it was decided to create a supervising organization able to constrain members of the medical profession active in the domain of transplantation. Beyond these irregularities, and beyond the control that lower level organizations tend to have over the scarce resource because they want to offer them to their "own" patients, this supervising organization has among its duties a proactive stance in the production of organs. In brief, to get the greatest possible control over the organs of brain-dead people; in the words of Blanca Miranda (2003), then at the head of the Spanish Organizacion Nacional de Trasplantes, the issue was to "optimize the pool of donors". At the inter-individual level, the issue of control of a scarce resource merges with the issue of power: this was the case when a heart surgeon claimed that when a person was brain-dead in his hospital, he would explain the situation to the family and then just tell them that, if they were not aware of the wishes of the dead person, he would remove organs for transplant (Cabrol 1987, p. 163). This full-blown application of the law of presumed consent was completely at variance with the way it was used by other surgeons, asking relatives for their authorization in collecting the organs of the deceased person. In the first case, the surgeon was bluntly claiming that he used all his symbolic power as a surgeon to gain access to organs.

Control and power relations also play a role in the domain of medically-assisted procreation. Due to the great importance given to anonymity in the case of biological donation, the organization for the collection of sperm was in France founded upon the same principle: there is no relation between the sperm donor and the couple and consequently, no possible relation between the children born as a consequence of the insemination of this sperm and the initial donor, whatever their wishes might be (Thery 2010). Initially, the centers that held the sperm destroyed personal information as soon as the sperm was used; now they keep their records for 30 years but they do not give any information to children, preventing them from obtaining full access to their identity. This represents a clear affirmation of the organization's power with respect to individuals in the donation chain.

Thirdly, it is important to consider the relational dimension of organizational gift-giving behavior. Viviana Zelizer's work - her proposal concerning the "circuits of commerce" (Zelizer 2005, 2011), and the relational dimension of her economic sociology (Zelizer 2012) — is a useful starting point. ${ }^{2}$ She has emphasized how important it is to consider relational work, that is how people involved in transactions mingling money and intimate relations are able to agree on subtle distinctions about their transaction. ${ }^{3}$ According to what has been said above, the relational work to be done does not limit itself to an agreement between the two parties of a given transaction: it may be necessary to take into account previous transactions (what was the nature of the transaction thanks to which the seller got the good?) or further possible transactions (what will the buyer do with the good?), or possible other parties who might emerge in future (children born from the selling/giving of sex cells). Study of the relations arising between young women working in go-go bars in Bangkok and their foreign customers, relations that mix sexuality and money, intimate feelings and payment (Roux, 2011) may illustrate the first point. Roux explains that these young women do not consider themselves to be prostitutes, and that the relation with their foreign male customers entails much more than sex for money, even if both are at the root of the relation usually labelled and condemned as sexual

2. See as well in this volume the chapters written by Kieran Healy and Nina Bandelj.

3. According to Zelizer there are four sets of variables to be considered: 1) specific social tasks among groups and individuals involved; 2) a set of transactions; 3) media (i.e. legal tender, token, goods, etc.) used in these transactions; and 4) negotiated meanings. 
tourism. Thaï women expect their regular foreign customers to "take care" of them, that is, to be provided with steady flows of money with which they can secure a living. And they themselves do likewise, "taking care" of their customer, haggling for them in local markets, ordering in the local language in restaurants, and acting in part as "tour guides", showing to their foreign friend parts of the city and of the country which they would not otherwise have known. The Thaï language translates the English word care into kae, a linguistic move that is culturally meaningful in itself, but all the more so when one bears in mind the fact that kae also has a deep cultural meaning for Thaï people. Roux explains that most of these women come from poor villages in which their families still try to make a living. Accordingly, being in the capital city they are expected to "take care" of their relatives and to send them the money necessary for the maintenance of the family home, or provide funds for the education of the youngest children. Furthermore, payments being not strictly related to sexual intercourse, an enduring relationship is established, notably in the case of a tourist going back and forth between his mother country and Thailand. This pattern fits very well into Zelizer's circuits of commerce and with the role that she assigns to culture within the economy: a monetary transfer is redefined in terms that allows both parties to have a legitimate say in what is occurring, and thus helps them to reproduce their social relationship. In other words, transactions do not occur singly and in isolation, as a unit separated from the previous transaction and that following. This is precisely what Roux demonstrates: the meaning attached to the money-sex transaction in the tourist-hostess relation in Bangkok is firmly connected to the fact that the meaning of "taking care" is aligned with the "taking care" meaning attached to the hostess-family transaction. This bears direct comparison with the gift relationship as Mauss viewed it, since for Mauss the gift is characterized by a series of gifts and counter gifts, propelled by the three obligations to give, receive and give back.

Furthermore, Zelizer's circuits of commerce are limited to face-to-face relations between persons. Curiously enough, no organization has a place in these circuits, or at least their presence is not taken into account. This is most surprising, since even in the case of transactions involving life and death, dependent people, care relations, and many intimate transactions, organizations are major actors confronting individual actors in their transactions. Of course, negotiations occur between human beings, but this is not exactly the same when one of them acts as the personification of an organization. Consideration of the role of organizations within circuits of commerce offers two interesting perspectives: on the one hand, they may render the negotiation more difficult - because of the rigidity of organizational scripts and administrative routines which may be beyond the reach of the person involved in the face-to-face relationship with a customer. As an example, one may think how reluctant medical staff once were, and still are, when faced with people willing to give a kidney to a friend or to an unmarried partner. The person willing to give is submitted to a series of legal and psychological examinations to ensure that the transaction fits the requirements of the organization, examination procedures which go beyond the medical requirements determining the good health of the donor. On the other hand, organizations may offer the possibility of going beyond face-to-face relations, and link the cultural shaping of transactions at the micro-level to political decisions and political debates at the macro-level. Once transactions are properly defined culturally and routinely implemented by organizations, these cultural meanings become more stable and are more likely to be taken for granted and accepted as resources for future transactions, even for a limited period of time. The idea of a series of transactions and organizations would thus render more powerful the economic sociology of circuits of commerce. This approach is has real value, and will be of use in guiding empirical research. However, the study of organisational gifts cannot be reduced to Zelizer's conception, since that does not take into account relations between persons and organisations, and so does not take account of the characteristics of the latter. To the extent that organisations are taken into account, it is necessary to question the formation and maintenance of the connections between individuals qua representatives of the organisation, and to study how interpersonal connections and impersonal interactions combine in elaborating and maintaining the social meanings characteristic of organisational gifts.

It is important to bear in mind the fact that the organizational gift implies that impersonal and personal relationships are present in the same sequence of transactions. Such a circuit of 
commerce involves both market exchange and gifts. The organizational gift belongs therefore to those kinds of transaction that blur the boundaries between the sphere of market exchange and that of personal relationships. All the same, the study of organizational gifts should be expanded beyond Zelizer's conception, since she does not take into account relations between persons and organizations, and so does not take account of the characteristics of the latter. And, to the extent that organizations are taken into account, it is necessary to question the formation and maintenance of the connections between individuals qua representatives of the organization, and to study how interpersonal connections and impersonal interactions combine in elaborating and maintaining the social meanings characteristic of organizational gifts. Second, organizational gift brings to the fore the issue of a longer relational chain than the one put forward in Zelizer's work. As mentioned above, when organizations enter the realm of donation, gift-giving behaviors entail a "two-stage donation" which generally transforms the individuals located at the opposite ends of the chain into strangers. But there are situations in which this process may make it possible for the individual who is one stage removed to obtain information, or even meet the person standing at the very beginning of the relational chain. In any case, the relational chain is here longer than that studied by Zelizer.

\section{Reciprocity and alternatives forms of exchange in modern economies}

The organizational gift is of inherent interest since it opens the door to an economic sociology of modern forms of gift, notably, but not exclusively, in the burgeoning field of biomedical commerce. However, I would like to suggest that it is also of interest because it provides an opportunity to enrich our understanding of the various arenas within which people engage in transactions, possibly involving choices between scarce goods, without actually completing a market exchange. Since Polanyi's mapping of these arenas is certainly the most often used I will start with a brief summary of his approach, cast in terms of forms of integration; then I will briefly explain how it is possible to elaborate his views through a focus on modern society.

\section{Polanyi's four types of economic integration}

In Trade and Market in Early Empires Polanyi proposed a general approach to the economy. This approach has two faces: the first concerns the famous distinction between formal and substantive views of the economy. This distinction has been subjected to extensive debate among anthropologists, and to a lesser extent among economists and sociologists: it is generally thought that the substantive approach did not survive the criticism. ${ }^{4}$ I will not consider this debate any further, and I limit my comment to one point that has been overlooked as a consequence of the opposition of formalism to substantivism. It is important to bear in mind the fact that Polanyi himself said that in modern society the substantive and the formal views merged. This is very much the case when one is compelled to offer one's labor in the market to earn one's living; in that case, any sharp distinction between the two forms almost vanishes, leaving open the question of how a Polanyian approach to the economy may be developed in such a situation. ${ }^{5}$

The second face of Polanyi's general approach to the economy has been subjected to much less scrutiny, and has been generally thought of as a general and robust map of the various arenas of commerce in societies, notably because his map is largely compatible with the one that Mauss offered in the concluding parts of his Essai sur le don, when he explained that there was "an atmosphere of gift" (Mauss 1925, p. 258) with the development of social welfare. This mapping distinguishes four forms of economic integration: autarky, reciprocity, redistribution and market exchange, and claims that these four forms may be at work simultaneously in any society, even if one form may have a clear supremacy. Polanyi himself gave an empirical example of the co-existence of these four forms in his posthumously published study of the kingdom of Dahomey during the $17^{\text {th }}$ and the $18^{\text {th }}$ centuries (Polanyi 1966).

The difference between the four forms are plain: autarky means an economic entity which is able

4. See Hann and Hart's presentation of this famous debate (Hann and Hart 2011, chap. 4).

5. According to this view, Zelizer's work can be read as an attempt to explore the "hyper-monetized" world in which the substantive and the formal approach of the economy merge (see Zelizer 2005, 2011). I have developed some aspects of this idea further in a previous paper (Steiner 2009). 
to provide for itself all the necessary elements of its economy; reciprocity means that there exist forms of exchange which involve commerce between groups of a given society, so that group A gives something to group B, which then reciprocates; redistribution means that a central agency collects part of what is produced by economic entities, and then redistributes a portion of the resources collected back to those entities; and, finally, market exchange involves the rules of exchange and of market price, and which depends on the relation between supply and demand. Central to this mapping is a strong connection between each form of exchange (or transfer of resource) and a given institution, ${ }^{6}$ such as the oikos or any other form of economically autonomous entity; symmetrical elements within a society, and especially families; central entities such as the State; and finally the market system, in the sense of a set of markets that generate prices free from any moral, religious or political regulation.

I do not want to challenge the mapping of the economy that Polanyi made to provide tools for anthropologists, historians and social scientists busy with archaic, historical and modern economic activity respectively. I would like to focus on the most modern forms of economic activity so that we might obtain a more precise mapping of the reciprocity form, for which organizational gift-giving is a component that has so far been overlooked.

\section{What "reciprocity" means in a market-system society}

Following the point of view that links the work of Polanyi and Mauss, it is clear that gift-giving practices belong to reciprocity. However, there are several forms of gift beyond those which one might make to friends and relatives.

From these gift-giving behaviors one must single out transfers of resource that take place among members of the same family or the same household - a household, or a maisonnée according to Bourdieu's conceptualization, is made up of

\footnotetext{
6. "The institution of the economic process vests that process with unity and stability; it produces a structure with a definite function in society; it shifts the place of the process in society, thus adding significance to its history; it centers interest on values, motives and policy [\&] The human economy, then, is embedded and enmeshed in institutions, economic and non-economic. The inclusion of non-economic is vital (Polanyi 1957, p. 148).
}

several nuclear families connected by kinship and solidarity. ${ }^{7}$ These are among the most important types of gift-giving practice, including social support for those in need of financial help during periods of economic crisis. To these direct gifts one should add bequests, an important transfer of resources that is almost completely overlooked by current work in economic sociology. ${ }^{8}$ Comte is probably the only great European sociologist to have stressed the importance of bequests among the forms of transfer of resources that he considered in the second volume of his massive Système de politique positive: gift-giving and market exchange as peaceful transfers, with conquest and bequest representing the violent side. ${ }^{9}$ However, gift-giving and bequests are directly linked in his economic sociology since they both belong to the domain of what Comte then called altruism - he actually coined the word - in contradistinction to conquest and market exchange, which are driven by self-regarding economic motivation, or egoism in Comte's vocabulary. While forgotten, Comte insights are relevant to market society today. French data related to bequest and donation, whether on the macro and the micro levels, are supporting Comte's view on the importance of bequest as a form of transmission of wealth. Economists interested in the macroeconomic role of bequest stress that with the growing importance of high incomes, the massive inequality that they create, and the

7. In his study of the economic habitus of Algerian people in the 1960's Bourdieu differentiated the nuclear family ( $m e ́-$ nage) from the household (maisonnée): "the real entity is not the nuclear family but the household, a group of individuals and families which disposes of an aggregation of small incomes, and provides a far better existence than each family would have if reliant on its own resources only. Group solidarity gives each individual and each family security against material and psychological destitution" (Bourdieu 1977, p. 100; my translation). See as well Florence Weber's work on this point (Weber 2002).

8. There are obvious exceptions to this, for example, Bourdieu's study of matrimonial strategies of land owning families (Bourdieu 1980, book II, chap. 1) and Jens Beckert comprehensive comparative analysis of American, French and German bequest legislations from the middle of the $18^{\text {th }}$ century to the present (Beckert 2004). I have limited my own research in this area to $19^{\text {th }}$ century France (Steiner 2008).

9. See Comte 1851-1854, II, p. 155. Philippe Descola has recently elaborated a general typology of "schemes of attachment" between humans and non-humans. He is led to distinguishing exchange, predation and gift on one side, production, transmission and protection on the other (Descola 2005, chap. 13). 
much greater inequality in accumulated assets held by those families at the top of the wealth distribution, developed societies are reinventing the $19^{\text {th }}$ century "dynastic economy". This means that the flow of wealth that moves, through both bequest and donation, from the older generation to its successor is steadily growing, amounting in 2008 to $15 \%$ of the French national income - a huge increase in comparison to the $4 \%$ of 1945 (Piketty 2011, p. 1073, figure I). On the other hand, sociologists interested in the micro behaviors of bequest and donation stress how strongly they are related, there being complex forms of calculation between those who have received more from their parents while young, and those who will receive more through bequest. This is especially important when there is an important dynastic asset, such as vineyard or a specific asset related to an entrepreneurial activity (a bakery for example), transmitted to one of the siblings. ${ }^{10}$

Finally, to these direct gifts should be added organizational gifts that represent a significant part of gift-giving behaviors in present-day market society. Beyond what has been said above, it is interesting to consider some data collected by the Fondation de France. In 2004, 55\% of French people gave money, goods or time. The report gives some detail: " $21 \%$ of the people interviewed have sent a check to an organization; $18 \%$ have directly given money to somebody asking money for herself, or for a charity organization; $14 \%$ have bought goods so that a part of the price went to charity; $2 \%$ have given through a monthly debit to their bank account, and 1\% through the internet page of the organization". ${ }^{11}$ A significant part of these gifts therefore involves organizations, which appears to be an inescapable part of gift-giving, and which is an issue for those in charge of charity fundraising since, according to the report, there is a tendency to give to organizations to which one has already given since they are assumed to be more reliable. The issue of trust is important, since it means that donors need to trust the organization if they are to be induced to give to a stranger.

10. See on this point the study on the Cognac industry (Bessière 2010), and the three family budgets examined in a recent $\mathrm{PhD}$ devoted to the sharing of resource among French poor households (Perrin-Heredia 2011, chap. 5).

11. Fondation de France, 2004, Baromètre de la générosité en France, p. 4 (See also Sylvain Lefevre 211).
Finally, it is important to stress that all these forms of reciprocity are grounded on a specific institution: the nuclear or extended family in the case of a direct gift and bequest; charity organizations in the case of indirect gifts. In this last case, organizations are the integrative dimension because they are linked through tariffs or set prices; ${ }^{12}$ secondly, because they convey power relation within circuits of commerce; and, finally, because they have a specific relational form.

\section{Forms of integration and the relational dimensions of economic integration}

The relational dimension of Polanyian mapping has been left untouched by commentators so far. The present enquiry suggests that this might be given some further consideration, and the relevant relational forms added.

The relational translation of the first three economic integrative forms does not raise difficulties (see figure 4a): autarky and oikos are represented by an isolate in a sociograph; reciprocity grounded on the family as an institution is represented by either dyadic symmetrical links (simple reciprocity), or by asymmetrical dyadic links forming a closed chain so that, in the end, any entity gives and receive; redistribution is represented by a graph in which one entity, and only one, is singled out by a maximal degree of centrality (i.e. this entity has a degree of centrality equal to 1 ).

The relational translation of the last form - the market system - is missing in Polanyi's writings. Based on the two fundamental principles of equilibrium economics, I suggest that a Walrasian and an Edgeworthian graph can be used to flesh out the relational dimension of the market system understood as an exchange of information (see Figure $4 \mathrm{~b}$ ), from which the matching of goods and person (the actual transactions) results.

In a Walrasian market participants, whether on the supply or on the demand side, are connected only to an auctioneer who is the central actor for the information graph, with a maximal degree of centrality, as in the redistribution form. However, in the market system the central entity does not collect resources that have been produced or demanded, but limits itself to centralizing

12. "Insofar as exchanges at a set rate is in question, the economy is integrated by the factors which fix that rate, not by the market mechanism" (Polanyi 1957, p. 154). 
Autarky

A

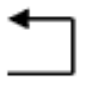

Reciprocity

A

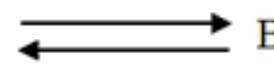

\section{Redistribution}

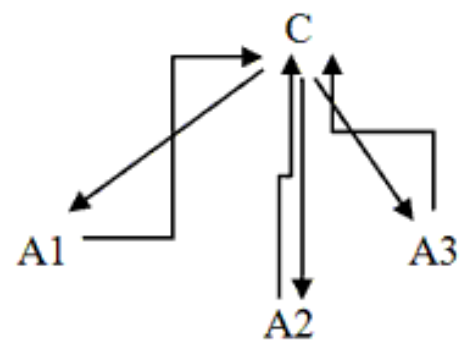

Figure 4b : Relational configuration of the market system

Walrasian

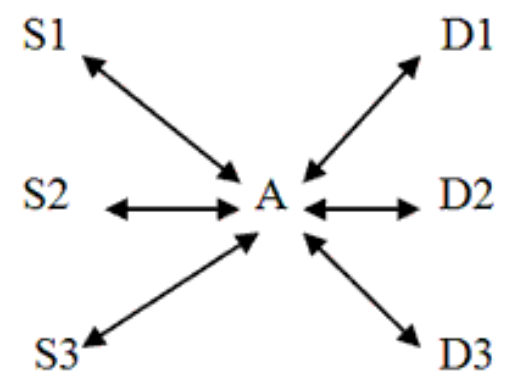

Edgeworthian

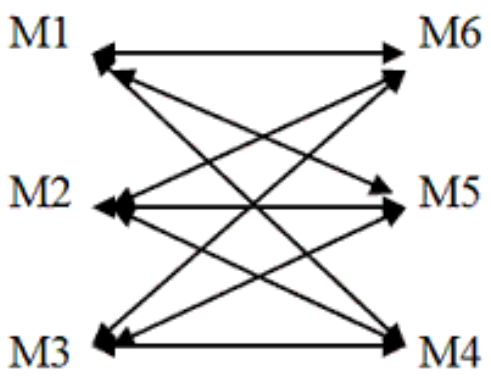

information so that equilibrium prices can be achieved; then a real exchange of resources may take place in the economy according to the distribution of preferences among market actors. ${ }^{13}$ In an Edgeworthian market, each market entity is directly connected with all the others in order to negotiate and re-negotiate the price so that, in the end, the market converges toward an equilibrium price, theoretically equal to the Walrasian equilibrium price if the number of entities involved is high enough.

How can the different forms of reciprocity mentioned above be translated into a relational graph? Let us first consider the organizational

13. See Michio Morishima's study of the Walrasian economy, and notably his demonstration of equivalence between this approach to general equilibrium through the so-called "tatônnement" process and the arbitrage process - the latter involves direct connections between market entities (Morishima 1977). When the information issue is solved, actual flows of exchanges depends on the matching technology of units demanded and supplied. In other cases, matching may produce specific exchanges structures, as demonstrated in the case of a financial market (Baker 1994). gift, the simplest form. In that case (see Figure 1), the relational translation involves a relational chain going from the individual placed at the start of the process when a gift is addressed to an organization; it then runs from this organization or series of organizations to the final individual at the end of the chain. The second form of reciprocity that I have considered is secondary redistribution among members of the household, or the household percolation of resources. In that case, the relational dimension is composed of a series of reciprocal exchanges between generations (Elderly, Parents, Children), duplicating itself from generation to generation and, as a consequence, reinforcing their protective strength when three generations are living during the same period of time. This relational structure may further be characterized by the fact that downstream flows surpass upstream flows, because the elderly transmit more than they receive from their children and grandchildren. Finally, the bequest relational system involves the various generations that receive and give resource through successive bequests in an open and never-ending process. 
Figure 5 : Percolation and bequest as form of economic integration

Percolation

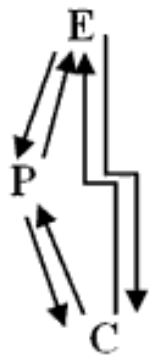

The percolation and bequest relational systems may be sketched in a simple form as in Figure 5. ${ }^{14}$

These two relational systems overlap at any given point in time, provided that the three (sometimes the four) generations are alive (Masson 2009). This means that both forms of reciprocity overlap because of the equity issue within families and because of legal rules, notably in the French law of bequest that requires that wealth donated be taken into account when it comes to determine the shares of each person entitled to the bequest. This is of great significance when the wealth of the past generation takes the form of vineyards that one of the children continues to cultivate (Bessières 2010).

\section{Conclusion}

All these forms of reciprocity amount to suggesting that, in our present market society, the transfer of resources outside market exchanges remains important; due to their importance in the domain of biological donation, it must be stressed that they are in no respect limited to older, even antiquated, forms of exchange.

However, reciprocity in our present market societies takes different routes, and is much more complicated than Mauss and Polanyi ever thought possible. Particularly important is the fact that organizations play a major role in making possible some of these forms of reciprocity. Specialization and the division of labor apply to

14. Both forms of transfer of resource are at work simultaneously in the family and the household (see Masson 2010, Bessière 2010). It is worth pointing out that percolation is an illustration of the combination of reciprocity and redistribution - since a part of the resource received in a household can come from governmental redistribution - which is a "way to gain in power" as Polanyi stated (Polanyi 1957, p. 153).

\section{Bequest}

reciprocity as they do to the market system. As a result, gift-giving is heavily modified: organizations are powerful and costly, they blur or prevent the direct relation between the donor and the donee and, finally they extend the chain running from the initiating individual to the final recipient. This new integrative system for the transfer of resources deserves the full attention of economic sociologists.

\section{References}

Almeling, Rene, 2011, Sex Cells. The medical market for eggs and sperm, Berkeley, the University of California Press

Avare, Philippe and Eynaud, Philippe, 2008, "L'autorégulation des associations faisant appel public au dons", in Christian Hoarau and JeanLouis LAVILLE (eds.), La gouvernance des associations. Economie, sociologie, gestion, Toulouse, Erès, p. 153-171

BARMAn, Emily, 2007, “An Institutional Approach to Donor Control: From Diadic Ties to a FieldLevel Analysis", American Journal of Sociology, 112(5), p. 1416-1457

Bessière, Céline, 2010, De génération en génération. Arrangements de famille dans les entreprises viticoles de Cognac, Paris, Le Seuil

Boltanski, Luc, 1993 [2007], La souffrance à distance. Morale humanitaire, média et politique, Paris, Gallimard

Bourdieu, Pierre, 1994, Raisons pratiques. Sur la théorie de l'action, Paris, Le Seuil

Bourdieu, Pierre, 1997, Méditations pascaliennes, Paris, Le Seuil 
CAillé, Alain and Godbout, Jacques, 1992, L'esprit du don, Paris, La Découverte

Chanial, Philippe, (ed.), 2009, La société vue du don, Paris, La Découverte

Coleman, James, 1982, The Asymetric Society, Syracuse, Syracuse university press

Comte, Auguste, 1851-54 [1890] Système de politique positive. Traité de sociologie instituant la religion de l'humanité, Paris, Garnier

Descola, Philippe, 2005, Par-delà nature et culture, Paris, Gallimard

Fondation de France, 2008, Les fondations en France en 2007. Fondateurs, secteurs d'intervention, poids économique, www.fondationdefrance.org

Hann, Chris and Hart, Keith, 2011, Economic Anthropology. History, Ethnography, Critique, London, Polity Press

Healy, Kieran, 2004, "Altruism as an Organizational Problem: The Case of Organ Procurement", American Sociological Review, 69(June), p. $387-404$

Healy, Kieran, 2006, Last Best Gifts. Altruism and the Market for Human Blood and Organs, Chicago, The University of Chicago press

Hochschild, Arlie, 2003, The Managed Heart, Berkeley, California university press

KARPIK, Lucien, 2007, L'économie des singularités, Paris, Gallimard

Masson, André, 2009, "Réciprocités indirectes : typologies et modèles économiques", in André Masson, Des liens et des transferts entre générations, Paris, édition de l'EHEss, p. 145-169

Mauss, Marcel, 1925 [1980] Essai sur le don. Forme et raison de l'échange dans les sociétés archaïques, in Marcel Mauss, Sociologie et anthropologie, Paris, Presses universitaires de France

Melh, Dominique, 2008, Les enfants du don. Procréation médicalement assistée : parents et enfants témoignent, Paris, Robert Laffont

Morischima, Michio, 1977, Walras' Economics. A Pure Theory of Capital and Money, Cambridge, Cambridge university press

Perrin-Heredia, Ana, 2010, Logiques économiques et comptes domestiques en milieux populaires. Ethnographie d'une "zone urbaine sensible”, PhD thesis, Université de ReimsChampagne Ardenne

Piketty, Thomas, 2011, "On the long-run evolution of inheritance in France, 1820-2050", Quarterly Journal of Economics, 126(3), p. 1071-1131

PolanyI, Karl, 1957 [1968] "The Economy as Instituted Process", in George DatTon (ed.) Primitive, Archaic and Modern Economies. Essays of Karl Polanyi, New York, Anchor Books, p. 139-174

Polany, Karl, 1966, Dahomey and the Slave trade. An Analysis of an Archaic Economy, Seattle, Washington university press

SteIner, Philippe, 2008, "L'héritage au 19e siècle en France : loi, intérêt de sentiment et intérêts économiques", Revue économique, 59(1), p. 73-95

Steiner, Philippe, 2009, "Society and the Modern Economy: Who Was Right? Polanyi, Zelizer or Both?", Theory and Society, 38(1), p. 97-110

SteIner, Philippe, 2010, La transplantation d'organes. Un commerce nouveau entre les êtres humains, Paris, Gallimard

Testart, Alain, 2007, Critique du don. Études sur la circulation non marchande, Paris, Syllepse

THÉRY, Irène, Des humains comme les autres. Bioéthique, anonymat et genre du don, Paris, Editions de l'EHESS

Titmuss, Richard, 1971 [1994], The Gift Relationship. From Human Blood to Social Policy, London, London School of Economics Books

Weber, Florence, 2002, "Pour penser la parenté contemporaine", in Danièle Debordeaux and Pierre Strobel (eds.) Les solidarities familiales en questions. Entraide et transmission, Paris, Librairie générale de droit et de jurisprudence, $p$. 73-106

Zelizer, Viviana, 2005, The Purchase of Intimacy, Princeton, Princeton university press

Zelizer, Viviana, 2011, Intimate Lives: How Culture Shapes the Market, Princeton, Princeton university press

Zelizer, Viviana, 2012, "How I Became a Relational Economic Sociologist and What Does that Mean”, Politics E' Society, 40(2), p. 145-174 


\section{Working Papers : la liste}

Hervé Le Bras, Jean-Luc Racine \& Michel Wieviorka, National Debates on Race Statistics: towards an International Comparison, FMSHWP-2012-01, février 2012.

Manuel Castells, Ni dieu ni maître : les réseaux, FMSH-WP-2012-02, février 2012.

François Jullien, Lécart et leentre. Ou comment penser l'altérité, FMSHWP-2012-03, février 2012.

Itamar Rabinovich, The Web of Relationship, FMSH-WP-2012-04, février 2012.

Bruno Maggi, Interpréter l'agir: un défi théorique, FMSHWP-2012-05, février 2012.

Pierre Salama, Chine - Brésil : industrialisation et "désindustrialisation précoce », FMSH-WP-2012-06, mars 2012.

Guilhem Fabre \& Stéphane Grumbach, The World upside down, China's $R E D$ and innovation strategy, FMSH-WP-2012-07, avril 2012.

Joy Y. Zhang, The De-nationalization and Re-nationalization of the Life Sciences in China: A Cosmopolitan Practicality?, FMSHWP-2012-08, avril 2012.

John P. Sullivan, From Drug Wars to Criminal Insurgency: Mexican Cartels, Criminal Enclaves and Criminal Insurgency in Mexico and Central America. Implications for Global Security, FMSH-WP-2012-09, avril 2012.

Marc Fleurbaey, Economics is not what you think: A defense of the economic approach to taxation, FMSHWP-2012-10, may 2012.

Marc Fleurbaey, The Facets of Exploitation, FMSH-WP-2012-11, may 2012.

Jacques Sapir, Pour l'Euro, l'heure du bilan a sonné: Quinze leçons et six conclusions, FMSH-WP-2012-12, juin 2012.
Rodolphe De Koninck \& JeanFrançois Rousseau, Pourquoi et jusquioù la fuite en avant des agricultures sud-est asiatiques?, FMSHWP-2012-13, juin 2012.

Jacques Sapir, Inflation monétaire ou inflation structurelle? Un modèle bétérodoxe bi-sectoriel, FMSHWP-2012-14, juin 2012.

Franson Manjali, The 'Social' and the 'Cognitive' in Language. A Reading of Saussure, and Beyond, FMSHWP-2012-15, july 2012.

Michel Wieviorka, Du concept de sujet à celui de subjectivation/dé-subjectivation, FMSH-WP-2012-16, juillet 2012.

Nancy Fraser, Feminism, Capitalism, and the Cunning of History: An Introduction, FMSH-WP-2012-17 august 2012.

Nancy Fraser, Can society be commodities all the way down? Polanyian reflections on capitalist crisis, FMSH-WP-2012-18, august 2012.

Marc Fleurbaey \& Stéphane Zuber, Climate policies deserve a negative discount rate, FMSH-WP-2012-19, september 2012.

Roger Waldinger, La politique au-delà des frontières : la sociologie politique de l'émigration, FMSHWP-2012-20, septembre 2012.

Antonio De Lauri, Inaccessible Normative Pluralism and Human Rights in Afghanistan, FMSHWP-2012-21, september 2012.

Dominique Méda, Redéfinir le progrès à la lumière de la crise écologique, FMSH-WP-2012-22, octobre 2012.

Ibrahima Thioub, Stigmates et mémoires de l'esclavage en Afrique de l'Ouest: le sang et la couleur de peau comme lignes de fracture, FMSHWP-2012-23, octobre 2012.

Danièle Joly, Race, ethnicity and religion: social actors and policies,
FMSH-WP-2012-24, novembre 2012.

Dominique Méda, Redefining Progress in Light of the Ecological Crisis, FMSH-WP-2012-25, décembre 2012.

Ulrich Beck \& Daniel Levy, Cosmopolitanized Nations: Reimagining Collectivity in World Risk Society, FMSH-WP-2013-26, february 2013.

Xavier Richet, L'internationalisation des firmes chinoises : croissance, motivations, stratégies, FMSHWP-2013-27, février 2013.

Alain Naze, Le féminisme critique de Pasolini, avec un commentaire de Stefania Tarantino, FMSHWP-2013-28, février 2013.

Thalia Magioglou, What is the role of "Culture" for conceptualization in Political Psychology? Presentation of a dialogical model of lay thinking in two cultural contexts, FMSHWP-2013-29, mars 2013.

Byasdeb Dasgupta, Some Aspects of External Dimensions of Indian Economy in the Age of Globalisation, FMSH-WP-2013-30, april 2013.

Ulrich Beck, Risk, class, crisis, hazards and cosmopolitan solidarity/risk community - conceptual and methodological clarifications, FMSH-WP-2013-31, april 2013.

Immanuel Wallerstein, Tout se transforme. Vraiment tout ?, FMSH-WP-2013-32, mai 2013.

Christian Walter, Les origines du modèle de marche au hasard en finance, FMSH-WP-2013-33, juin 2013.

Byasdeb Dasgupta, Financialization, Labour Market Flexibility, Global Crisis and New Imperialism - A Marxist Perspective, FMSHWP-2013-34, juin 2013.

Kiyomitsu Yui, Climate Change in Visual Communication: From 'This is 
Not a Pipe' to 'This is Not Fukushima', FMSH-WP-2013-35, juin 2013.

Gilles Lhuilier, Minerais de guerre. Une nouvelle théorie de la mondialisation du droit, FMSH-WP-2013-36, juillet 2013.

David Tyfield, The Coal Renaissance and Cosmopolitized Low-Carbon Societies, FMSH-WP-2013-37, juillet 2013.

Lotte Pelckmans, Moving Memories of Slavery: how hierarchies travel among West African Migrants in Urban Contexts (Bamako, Paris), FMSH-WP-2013-38, juillet 2013.

Amy Dahan, Historic Overview of Climate Framing, FMSHWP-2013-39, août 2013.

Rosa Rius Gatell \& Stefania Tarantino, Philosophie et genre: Réflexions et questions sur la production philosophique féminine en Europe du Sud au $X X^{e}$ siècle (Espagne, Italie), FMSHWP-2013-40, août 2013.

Angela Axworthy The ontological status of geometrical objects in the commentary on the Elements of Euclid of Jacques Peletier du Mans (15171582), FMSH-WP-2013-41, août 2013.

Pierre Salama, Les économies émergentes, le plongeon?, FMSHWP-2013-42, août 2013.

Alexis Nuselovici (Nouss), L'exil comme expérience, FMSHWP-2013-43, septembre 2013.

Alexis Nuselovici (Nouss), Exiliance : condition et conscience, FMSH-WP-2013-44, septembre 2013.

Alexis Nuselovici (Nouss), Exil et post-exil, FMSH-WP-2013-45, septembre 2013.

Alexandra Galitzine-Loumpet, Pour une typologie des objets de l'exil, FMSH-WP-2013-46, septembre 2013.

Hosham Dawod, Les réactions irakiennes à la crise syrienne, FMSHWP-2013-47, septembre 2013.

Gianluca Manzo, Understanding the Marriage Effect: Changes in
Criminal Offending Around the Time of Marriage, FMSH-WP-2013-48, GeWoP-1, octobre 2013.

Torkild Hovde Lyngstad \& Torbjørn Skarðhamar, Understanding the Marriage Effect: Changes in Criminal Offending Around the Time of Marriage, FMSH-WP-2013-49, GeWoP-2, octobre 2013.

Gunn Elisabeth Birkelund \& Yannick Lemel, Lifestyles and Social Stratification: An Explorative Study of France and Norway, FMSHWP-2013-50, GeWoP-3, octobre 2013.

Franck Varenne, Chains of Reference in Computer Simulations, FMSH-WP-2013-51， GeWoP-4, october 2013.

Olivier Galland \& Yannick Lemel, avec la collaboration d'Alexandra Frenod, Comment expliquer la perception des inégalités en France?, FMSHWP-2013-52, GeWoP-5, october 2013.

Guilhem Fabre, The Lion's share : What's behind China's economic slowdown, FMSH-WP-2013-53, october 2013.

Venni V. Krishna, Changing Social Relations between Science and Society: Contemporary Challenges, FMSHWP-2013-54, november 2013.

Isabelle Huault \& Hélène RainelliWeiss, Is transparency a value on OTC markets? Using displacement to escape categorization, FMSHWP-2014-55, january 2014.

Dominique Somda, Une bumble aura. Les grandes femmes au sud de Madagascar, FMSH-WP-2014-56, january 2014.

Débora González Martínez, Sur la translatio de miracles de la Vierge au Moyen Age. Quelques notes sur les Cantigas de Santa Maria, FMSHWP-2014-57, janvier 2014.

Pradeep Kumar Misra, The State of Teacher Education in France: $A$ Critique, FMSH-WP-2014-57, january 2014.

Naeem Ahmed, Pakistan's Counterterrorism strategy and its Implications for domestic, regional and international security, FMSH-WP-2014-59, january 2014.

Anatole Fogou, Histoire, conscience historique et devenir de l'Afrique : revisiter l'bistoriographie diopienne, FMSH-WP-2014-60, january 2014.

Pierre Salama, Les classes moyennes peuvent-elles dynamiser la croissance du PIB dans les économies émergentes?, FMSH-WP-2014-61, février 2014.

Marta Craveri \& Anne-Marie Losonczy, Growing up in the Gulag: later accounts of deportation to the USSR, FMSH-WP-2014-62, february 2014.

Philippe Steiner, The Organizational Gift and Sociological Approaches to Exchange, FMSHWP-2014-63, GeWoP-6, february 2014.

Françoise Bourdarias, JeanPierre Dozon \& Frédéric Obringer, La médecine chinoise au Mali. Les économies d'un patrimoine culturel, FMSH-WP-2014-64, février 2014. 


\section{Position Papers : la liste}

Jean-François Sabouret, Mars 2012 : Un an après Fukushima, le Japon entre catastrophes et résilience, FMSH-PP-2012-01, mars 2012.

Ajay K. Mehra, Public Security and the Indian State, FMSHPP-2012-02, mars 2012.

Timm Beichelt, La nouvelle politique européenne de l'Allemagne: L'émergence de modèles de légitimité en concurrence?, FMSHPP-2012-03, mars 2012.
Antonio Sérgio Alfredo Guimarães, Race, colour, and skin colour in Brazil, FMSHPP-2012-04, july 2012.

Mitchell Cohen, Verdi, Wagner, and Politics in Opera. Bicentennial Ruminations, FMSHPP-2012-05, may 2013.

Ingrid Brena, Les soins médicaux portés aux patients âgés incapables de s'autogérer, FMSHPP-2013-06, avril 2013.
Thalia Magioglou, Refaire l'Europe ou refaire le "monde"? Un commentaire sur l'ouvrage : "Refaire l'Europe avec Jürgen Habermas ", FMSHPP-2013-07, septembre 2013.

Samadia Sadouni, Cosmopolitisme et prédication islamique transfrontalière: le cas de Maulana Abdul Aleem Siddiqui, FMSHPP-2013-08, septembre 2013.

Alexis Nuselovici (Nouss), Étudier l'exil, FMSH-PP-2013-09, septembre 2013. 